\title{
Certification of The Islamic Economic Judges in The Consumer Protection Perspective
}

\author{
Ro'fah Setyowati ${ }^{1}$, Muhyidin Mughni ${ }^{2}$, Aisyah Ayu Musyafa ${ }^{3}$, Hendro Saptono $^{4}$, Mas' $^{{ }^{\prime}}{ }^{5}$ \\ \{rofah@live.undip.ac.id ${ }^{1}$, arfi27@gmail.com ${ }^{2}$, aisyahayumus@gmail.com ${ }^{3}$, \\ hendrosaptono@gmail.com ${ }^{4}$, utmsi@yahoo.co.id $\left.{ }^{5}\right\}$ \\ 1,2,3,4,5 Faculty of Law Diponegoro University, Semarang Indonesia
}

\begin{abstract}
This article aims to assess the regulation of the Islamic economic judge certification from perspective of consumer protection. Philosophical and juridical approaches, have been used in this study. The results of this study include: certification of important Islamic economic judges to ensure Islamic economic disputes are settled in accordance with sharia principles. This is called sharia compliance. Thus, sharia compliance is a right for consumers of Islamic financial institutions. In other words, the certification of Islamic economic judges is one of consumer protection, especially in the spiritual aspect. This provision has been explicitly contained in the Supreme Court Regulations, especially in terms of the mechanism and content of the certification material.
\end{abstract}

Keywords: certification; Islamic economic judge; consumer protection.

\section{Introduction}

Islamic economic judge is an important factor in the development of Islamic economics in Indonesia. In legal studies, this topic is part of law enforcement factors, especially in the Religious Courts.

Islamic economics has become the most important instrument in the development of the world economic system. In Indonesia, the Islamic economy has the greatest potential in the world. This can be understood, because the number of Muslims in Indonesia, the most in the world. 87 percent of Indonesia's total population is equivalent to around 13 percent of the world's Muslim population. Based on this number, Indonesia can be decisive in developing the world Islamic economy.[1] Another thing that supports the statement is the contribution of Islamic economics in supporting the national economy.[2] The existence of the Islamic economy has contributed USD3.8 billion in Gross Domestic Product (GDP) every year. In addition, the Islamic economy is also able to generate USD1 billion in foreign direct investment, as well as opening 127 thousand new jobs each year.[3]

The results of previous studies,[4] judges have an important role in law enforcement and development in Indonesia. However, in reality, the distrust of the bank was directed to the judges in the religious court. This is an obstacle in increasing consumer confidence in the Religious Courts in dispute resolution.[5] Islamic banking considers that the competence and understanding of judges is considered to be less ready. This can be seen from the inappropriate judge's decision. In addition, although there is a Constitutional Court Decision Number 93 / 
PUU-X / 2012 which has strengthened the absolute competence of resolving Islamic banking disputes in the Religious Courts, but, in fact, there are still cases that are resolved to the General Courts. Based on these problems, the Supreme Court seeks to improve the quality of judges in resolving Islamic economic disputes, with regulations on the certification of Islamic economic judges.

This article aims to find the relationship between the Supreme Court Regulations on Islamic Economics Judge Certification and the concept of consumer protection. In this study philosophical and juridical approaches are used. The philosophical approach is used to understand the fundamental needs of consumers in the resolution of Islamic economic disputes. While the juridical approach is used to identify the Supreme Court judges' regulations in handling Islamic economic disputes. Data analysis in this study was carried out qualitatively with steps as Suteki's view of doctrinal research.[6] The analysis is carried out in depth by exploring the basic norms contained in the regulation. Meanwhile, the perspective of consumer protection in this article, is intended to map consumer rights that can be fulfilled through these regulations.

Based on the description above, this article aims to elaborate the Supreme Court regulations regarding the certification of Islamic economic judges, in supporting the enforcement of Islamic economic law in Indonesia. In addition, it was also examined about the possibility that the spiritual rights of consumers could be protected through the mechanism and content of the certification. The results of this study can be used to evaluate the provisions related to Islamic economic judge certification. Furthermore, improving the quality of these judges, is expected to support the enforcement of Islamic economic law to be more comprehensive and effective. This is useful for increasing public confidence in the competence of judges in the Religious Courts.

\section{Islamic Economics Judge Certification}

Carolyn H. Lindberg[7] stated that certification is a guarantee of competence through testing; as a method of granting professional status; and as a tool to distinguish professional work from one another. From this view it can be understood that certification is a verification process that is related to improving the quality of professionalism by using regulations or legality. This process is also a strategy to get competency standards for a profession. With these standards, it is easy to get recognition from the wider community.

The definition of certification above, as stated in Article 3 of the Supreme Court regulations referred to, states that "Sharia economic judge certification aims to improve the effectiveness of handling sharia economic cases in the Religious Courts as part of efforts to uphold sharia economic law that meets the sense justice. "This case, if related to the context of this study, it can be understood that Islamic economic judges are a special profession of the judge's profession in general. That is, to get competence as a judge of Islamic economics, needed certain mechanisms and measurable requirements. This, as stated in the Republic of Indonesia Supreme Court Regulation Number 5 Year 2016 concerning Sharia Economic Judge Certification, Article 1 "Sharia Economic Judge Certification is the process of awarding a judge's certificate that has been declared to have passed administrative selection, competence, integrity and training to become sharia economic judges. "And" Sharia Economic Judge is a religious court judge who has been certified and appointed by the Chairman of the Supreme Court of the Republic of Indonesia. " 


\subsection{Urgency of Certification for Judges}

Certification of Islamic economic judges in dispute resolution is an important part of law enforcement. In Sudikno Mertokusumo's view,[8] there are three elements that must be considered in law enforcement, namely: legal certainty (rechtssicherheit), expediency (zweckmassigkeit), and justice (gerechtigkeit). These elements are known as the pillars of the ideals of the law (idee des Rechts).[9] The intended legal ideal is needed to guide humans in using the law. Because these three elements are important, the judge who has the primary role in law enforcement, must be able to formulate decisions containing these three elements.

Related to law enforcement, according to Satjipto Rahardjo,[10] the creativity of law enforcers needs to take advantage of the opportunity to improvise in exploring and finding laws that are appropriate to the needs of the community. This is important in law enforcement and development. Therefore, the competence of judges in handling a dispute is a fundamental issue that is important to be considered, in order to obtain a decision that suits the needs of justice seekers. Such a view is known as a progressive legal perspective. Progressive law emphasizes that law should not be positioned as an absolute and autonomous document, but rather must be integrated with the real needs of the justice-seeking community. Specifically, with regard to litigation, judges have the greatest role in ensuring how to apply the law.[11] That is how Satjipto Rahardjo[12] introduced the character of progressive courts or progressive legal thinking in the context of the court.

Furthermore, referring to Satjipto's view, the judges are expected to be able to grasp the meaning behind the regulatory texts, so that their decisions are not bound by legal concepts that have been formulated in the legislation. In resolving Islamic economic disputes, this attitude is needed, because there is still a legal vacuum and some laws are not in harmony with other laws, which are related to Islamic economics.

In the context of law enforcement, the role of judges, especially in applying and finding law, is reflected in their decisions. Meanwhile, the process of finding law needs more attention than the application of the law. This is because in the process of finding a law (rechtsvinding), it is a very wide space for judges to make new laws that are in accordance with their conscience. Furthermore, this also reflects the involvement of the spiritual aspects of judges as lawmakers through their decisions. The involvement of spiritual aspects in the resolution of Islamic economic disputes is very strong. This is because there is a strong philosophical relationship between Islamic financial institutions with Islamic law and customers. This will be explained more fully, in the next section. In resolving Islamic economic disputes, the Supreme Court has made a provision through Article 2 that "Sharia economic matters must be tried by certified sharia economic judges and appointed by the Chief Justice of the Supreme Court of the Republic of Indonesia." Furthermore, it is strengthened by Article 5 (1) that "Economic matters sharia must be tried by sharia economic judges ". Likewise, Article 20 (1) states that "Sharia economic cases at the first court and appellate court within the religious court must be tried by a panel of judges whose head of the assembly and/ or one of its members is a Sharia Economic Judge. Even so, in certain cases, there are still exceptions as contained in Article 26, "In the event that there is no certified Sharia Economic Judge yet, sharia economic cases are examined, tried and decided by judges who have participated in sharia economic training." This provision is effective from 20 April 2016. Based on these 
provisions, the urgency of Islamic economic judge certification is an important requirement for the enforcement of Islamic economic law in Indonesia.

The requirements to become a judge of Islamic economics are contained in Article 6 Paragraph (1), that "To be appointed as a judge of Islamic economics must meet the following criteria: a. administrative requirements; b. competency requirements; c. integrity requirements; d. attend training; and e. has been declared passed by the Selection Team. "And Paragraph (3), that the Competency Requirements as referred to in paragraph (1) letter b at least include: a. able to understand Islamic economic legal norms; b. able to apply law as an instrument in trying Islamic economic cases; c. able to do legal discovery (rechtsvinding) to realize justice; and $\mathrm{D}$. able to apply the legal guidelines in trying Islamic economic cases.

\subsection{The Role of Judges in Sharia Economic Disputes}

At this point, discussing the function of Islamic economic judges in law enforcement practices in Indonesia with a juridical philosophical approach. In the legal system in Indonesia, there are principles in law enforcement. The main principle in the justice system is separation jurisdiction. The purpose of the principle is that in carrying out the justice system, it has been divided according to the field and jurisdiction or its competence. The division of the legal field is known as absolute competence, while the division of territory, is called relative competence.

The principle of Islamic personality can be seen clearly in Law No. 3 of 2006 concerning amendments to Law No. 7 of 1989 concerning Religious Courts. In summary, the principle of personality is based on Islamic legal subjects and / or uses Islamic law, both naturally and with voluntary submission, and the object of the law has been mentioned in the scope of competence, as stipulated based on relevant laws.

Islamic economic disputes are disputes relating to the implementation of economic and financial activities carried out under Islamic law. Therefore, in this article, this is called the Islamic economic dispute. The legal basis for settling Islamic economic disputes is regulated in Article 49 of Law Number 3 of 2006 concerning Amendment to Law Number 7 of 1989 concerning Religious Courts. In the elucidation of Article 49 it is stated that "Settlement of disputes is not only limited in the field of sharia's banking, but also in other sharia economics fields." Furthermore, "What is meant by" among people who are Muslims "includes persons or legal entities who automatically submit themselves voluntarily to Islamic law regarding matters under the authority of the Religious Courts in accordance with the provisions of this Article." The definition of "Syariah economy" is an act or business activity carried out according to sharia principles, including covering various Islamic financial institutions as they operate in Indonesia today, as well as existing sharia business institutions that will develop in the future.

The legal basis is strengthened by Law No. 21 of 2008 concerning Islamic Banking. Article 55 of the law states that "(1) Sharia Banking dispute settlement is carried out by courts within the Religious Courts environment; (2) In the event that the parties have agreed to settle a dispute other than as referred to in paragraph (1), the dispute resolution shall be carried out in accordance with the contents of the Agreement; (3) Settlement of disputes as referred to in paragraph (2) must not be in conflict with the Sharia Principle. "in this provision, it is explicitly stated that the main judicial institution obtaining competence in resolving disputes is the religious court. In addition, there are requirements that the dispute resolution process is in accordance with Islamic principles. The guarantee of the application of Islamic principles in 
the resolution of Islamic economic disputes will further strengthen the urgency of Islamic economics judges getting special certification.

In addition, the absolute competence of Islamic economic disputes was also confirmed by the Constitutional Court Decree No. 93 / PUU-X / 2012 issued on August 29, 2013. Thus, legally formal, the resolution of Islamic economic disputes had a strong foundation. However, in its implementation it still requires strengthening in the field of institutions, especially human resources, on the quality of the judges. This is necessary to increase public confidence in Religious Court judges. Therefore, regulations regarding the certification of Islamic economic judges are important to overcome these problems.

In order to overcome this problem, the Supreme Court, especially the Religious Courts Agency has made an effort, to increase public confidence in the new task. Since the beginning the competency was charged to the Religious Courts in 2006 based on Law no. 3 of 2006 concerning Religious Courts. In fact, some of the results of these efforts to date, there have been cases of Islamic banking that have been submitted and resolved within the Religious Courts. Judges who handle Islamic banking disputes in the Religious Courts have been specially prepared through various educational programs to the certification mechanism. Until 2014 there were more than 300 certified Sharia economic judges.[13]

The types of Islamic economic dispute cases that reached the cassation level, according to the highest order are murabaha transactions, namely $47 \%$, cucaracha $11 \%$, modaraba $18 \%$, and the rest of the execution of collateral such as mortgage, fiduciary, and sharia liens as much as $24 \%$. This situation certainly requires the quality and ability of qualified law enforcement officials to try the case.[14] For the settlement of economic dispute cases, there are two types of sharia economic dispute settlement as stipulated in the Supreme Court Regulation No. 14 of 2016 concerning Procedures for Sharia Economic Dispute Resolution, namely: First, with a simple event, where in 2017 there were 127 cases that could be resolved by this event. Secondly, with the usual program in 2017 there were 471 cases resolved by the religious court. [15] The Religious Courts already have material laws which are used as a basis for legal considerations in the process of making judges' decisions in the form of Sharia Economic Law Compilation, based on High Court Regulation (PERMA) No. 02 of 2008.

In the context of this study, the characteristics of sharia principles as described above, are philosophical consequences in the resolution of Islamic economic disputes. Specifically, in Islamic banking, it represents other Islamic financial institutions. This is because there is a common Islamic philosophy which is the initial foundation for the operation of Islamic financial institutions. This is because the legal basis of other Islamic financial institutions does not yet have a complete regulation, so logically, it is appropriate to use the dispute resolution model in Islamic banking. In this case, the obligation of judges to be bound by Islamic principles is clearly regulated. Therefore, in order to fulfill these requirements, the obligation of Islamic economic judges to take part in certification is an absolute necessity.

Based on this article, the Panel of Judges in the trial of Islamic economic disputes must carry out the entire process up to the decision making by committing to legislation that is not contrary to Islamic principles. This means, if in the trial process, the Panel of Judges finds legislation contrary to sharia principles, or the legal basis that has not been found to be needed for the case, then the judge must explore and find the right law (rechstvinding). This becomes part of the obligation for Judges when the source of reference is limited or even non-existent.

1. Towards Islamic Economics Judge certification 
Before reaching the special certification stage as regulated in Supreme Court regulations, several efforts have been made to improve the quality of human resources as follows:

a. Sharia Economics Judge Certification Training:

- Organized by the Supreme Court Training Center, and the State Administration Agency;

- Sharia Economic Judge Certification Training has been carried out by several forces,

namely: 1) Class I in 2013 with 120 participants; 2) Class II of 2016 with 120 participants; 3) Class III of 2017 with 120 participants; 4) Class IV of 2018 with 45 participants;

b. Sharia Economy Technical Guidelines (Bintek) for Religious Court judges conducted by the Supreme Court Training Center, Religious Court Body (Badilag) and the Religious High Court in collaboration with the Financial Services Authority, banking institutions such as May Bank Syariah, and so forth which have produced more than 1,500 judges who have participated Such Bintek throughout Indonesia;

c. Collaborative training, discussion and study of Sharia Economics with related agencies (Financial Services Authority or OJK, Bank Indonesia, National Sharia Council, Indonesian Ulema Council, Sharia Economic Community or DSN) also took part in FGDs organized by OJK and DSN) also took part in the FGDs that were held by OJK and DSN;

d. Cooperation of Sharia Economic Training with abroad:

- Ibnu Saud University, Saudi Arabia, while the Sharia Economic Training and Training in Riyad, Saudi Arabia has been implemented as many as four generations. Class I in 2009 had 40 participants, Class II in 2012 had 40 participants, Class III in 2015 had 40 participants and Class IV in 2016 had 39 participants, and now 40 participants have also been prepared to be trained in the country.

- Sudan Supreme Court There are 6 (peoples) judges of religious courts who study Islamic economics at the Khartoum University of Sudan at the Doctoral level and now there are two Religious Court judges currently attending the Doctoral Sharia economic concentration.

- Comparative study of Islamic economics with Kuwait, Morocco, Qatar, Bahrain, Oman, Jordan, Turkey, Egypt, and the United Kingdom for organizing Islamic economic training courses for Religious Court judges, as well as signing of MoUs in exchange of information and training of judges from each country;

e. Holding an MoU with domestic tertiary institutions for Master and Doctoral education for Religious Courts judges specializing in sharia economic law as has been done by the Surabaya High Court of Religion with Bandung Islamic University 
and Muhammadiyah University of Surabaya, as well as the Medan High Court of Religion with the Islam State University of North Sumatra, and other universities.

The quality of the education of the judges which has improved significantly shows the responsiveness of the Religious Courts in preparing the new authority. In addition, in the training of judges in the field of sharia economics, both banks and other sharia economic institutions, which are conducted for 5 consecutive days, contain a variety of materials needed, including: Legal Aspects of Islamic Banking, Sharia Micro Bank and Rural Bank, Compilation of Sharia Economic Laws, Sharia Investment Law (Capital Market, bonds and sharia mutual funds), Legal Aspects of Islamic Financial Institution Pension Funds, Settlement of Islamic economic disputes, Legal Aspects of Sharia Economics, Sharia Insurance and Reinsurance Law, Contract Law in Islam, Mediation in Settlement of Islamic Economic Disputes, Sharia Pawnshop Law, Endowment Law (Juridical Review of Law No. 41 of 2004), Indonesian Zakat Law.

In addition to some of the material above, in training in smaller and shorter shovels, materials about: a. The Role of the National Sharia Council in the Development of the Sariah Economy; b. Annotation of Sharia Economic Decisions; c. Murabaha. d. Modaraba.

In the practice of training in Islamic economics in several Religious Courts, the material delivered in the training varied include: a). Sharia Economic Material Laws both from the classical book of contemporary and Fiqih; b). Islamic Jurisprudence, including taking law from the Qur'an and Hadith texts) and others in accordance with their respective local conditions. When viewed from the content of training materials and improving the educational levels of the religious court judges above, it shows their sincerity in the effort to carry out this new task. Intensive socialization of the development of Islamic economic law and the high interest of judges to follow it, also strengthened the awareness and mental readiness of the Religious Courts in the Supreme Court.

\subsection{Consumer Protection}

\section{1) Financial Services Consumer Protection}

In order to find the relationship between the certification of Islamic economic judges and consumer protection, it will examine the rights of consumers and the roadmap of consumer protection that shows the direction of policy development of consumer protection in the future.

In the Roadmap for consumer protection for financial services, various strategies have been set to provide integrated protection. This strategy is a series of efforts to harmonize efforts that prioritize the availability and improvement of infrastructure quality, regulation, market conduct supervision and communication education implementation. This is part of an effort to create a culture of fair treatment of consumers (treating customer fairly).[16] This aims to make people feel comfortable and safe when utilizing financial products and/ or services. Likewise, in the event of a dispute between financial service institutions and their consumers.

Four important elements of SPKK consisting of infrastructure, regulations, market conduct supervision, and communication education are important tools needed to realize the building of public trust and level playing fields in the financial services sector.[16] The consumer protection system compiled by the Financial Services Authority regulates the responsibilities 
of consumers and financial service institutions, the availability and operation of supporting infrastructure for dispute resolution, the role of regulators in providing direction and conducting joint supervision and efforts to build a culture of treating customers fairly in the financial services sector. The application of consumer protection follows the product life cycle approach through the application of the principle of consumer protection since the product is designed, marketed, utilized and when disputed.

Muhammad Akbar Khan [17] argues, that every country is obliged to play a role to protect all fundamental individual rights and freedoms that are derivate. The state obligations referred to consist of: (1) The state must guarantee that every Muslim implements his religion, in accordance with the first objective. (2) The State must guarantee the security and welfare of all human beings under its administration, this is done by providing clothing, food and shelter to ensure the life and safety of all humans, in accordance with the second objective. (3) The state must provide and facilitate conditions for the growth of a healthy mind, such as by giving freedom of expression and universal education, in accordance with the third objective. (4) The state must create conditions for a healthy family system, in accordance with the fourth objective. (5) Finally, the state must guarantee the overall economic prosperity of the people, which can be used to implement the first four objectives, in accordance with the fifth goal.

\section{2) Protection of Customers of Islamic Financial Institutions}

Islamic banking is fundamentally different from conventional banking. This is recognized and mentioned in the considerations letter $\mathrm{c}$ of the Sharia Banking Law. For Islamic banking, "the application of Islamic principles" is an important icon in running its business. This is a "corporate identity" in Indonesia symbolized by "IB" (Islamic Banking). "IB" as a corporate identity, underpinned by the philosophy of Islamic teachings to do interaction in society (muamalat) according to sharia, has very broad consequences on various aspects in carrying out Islamic banking operations. All aspects must be linear with Islamic principles. One important aspect of them is in dispute resolution which is part of law enforcement in Islamic banking.

The relationship between Islamic banking and Islamic law or Islamic principles is a philosophical relationship. This means that the relationship is very basic, and it can even be said that the emergence of Islamic banking is based on the spirit to practice Islamic law in kaffaah (overall). This understanding has been recognized and published legally in Indonesia, as outlined in the term 'Islamic principles' in Act Number 21 of 2008 concerning Sharia Banking.

The use of the word 'sharia' which refers to the meaning of 'Islamic sharia' as a source of legislation, looks specifically at the inclusion of sharia, such as sharia banking, sharia insurance, sharia economics and so on. Sharia principles are based on the values of justice, benefit, balance and universality (rahmatan lil'alamin). These values are applied in banking settings, so called Sharia Banking. Thus, it can be concluded that if a bank declares itself to be a sharia bank, then to the bank, Islamic law applies, especially in the scope of muamalat, other than banking law in general. The relationship between Islamic banking and religion and Islamic law, can be understood more clearly by looking at the relationship between a Muslim and Islamic law.

The many mention of "sharia principles" as described above shows that religion in the context of state life in Indonesia cannot be ignored. Indonesia is not a religious state, but neither is it a country that places religion within the private sphere. Indonesia places religion 
in a strategic position as a moral and ethical system. The government pays great attention to religious life. This includes carrying out transactions through Islamic financial institutions to resolve disputes that may arise in their implementation.

If it is related to the results of research that has been conducted, then basically the most important things needed in meeting the requirements of conformity with sharia principles in the settlement of Islamic banking disputes are at least the following: [4] (1) Judges / arbitrators / mediators who handle matters of Islamic banking disputes must have Islamic economic legal competence and muamalat fiqih, especially related to the field of Islamic banking; (2) Legislation referred to by judges in the judicial process to provide legal considerations, is not contrary to Islamic principles; 3 ) In addition, organized by the institution and with appropriate procedures. In connection with the foregoing, in this paper the author only highlights the resolution of Islamic banking disputes carried out by the Religious Courts.

The results of the above study if linked to the views of Akbar Khan as quoted by Lerner [18] which states that the act to practice religion, and freedom to practice religion are fundamental rights of individuals. Therefore, drawn from a philosophical approach, the state also has an obligation to provide protection for these rights. In the context of this study, fulfillment of sharia principles in the resolution of Islamic economic disputes. One mechanism is through the certification of Islamic economic judges.

By adopting an analogy to the realization of the guarantee of economic welfare for Muslim consumers, it can be said that the existence of certification for sharia economic judges can also affect the efficiency and public trust in sharia-compliant services.[19] With the guarantee of sharia compliance (shariah compliance) through strengthening the certification of Islamic economic judges, Muslim consumers get a sense of security and comfort in making transactions through Islamic financial institutions.

\section{Conclusions \& recommendation}

From the description above, it can be found that there is a direct relationship between the certification of Islamic economic judges with consumer protection. The relationship is in the form of a guarantee of strengthening the application of sharia principles. Meanwhile, from the perspective of consumer protection, the application of sharia principles is one form of the spiritual rights of consumers who are obliged to get protection from the state. Thus, the certification of Islamic economic judges in the perspective of consumer protection, is the protection of consumer rights in the spiritual aspect.

In order to improve the stage of its implementation, certification with material that has been prepared in a standardized manner, should be delivered by resource persons who have experience in the practice of deciding cases. Therefore, the Supreme Court Training Center, and the State Administration Agency, should be able to ensure that collaboration in providing training materials and certifying Islamic economic judges must pay attention to the capacity of resource persons who truly understand Islamic economic issues in Indonesia in practice. Thus, the value of the benefits can be captured more strongly.

\section{References}

[1] Thomson Reuters, "State of the Global Islamic Economy."

[2] Indonesia Halal Lifestyle Center, "Indonesia Halal Economy and Strategy Roadmap." Indonesia Halal Lifestyle Center, p. 29, 2018. 
[3] F. Rosadi, "Indonesia Mesin Ekonomi Syariah Dunia, article in Media Keuangan Magazine," Finance Ministry of Republic Indonesia, Jakarta, p. 57, 2019.

[4] R. Setyowati, "Penyelesaian Pertikaian Perbankan Islam di Indonesia dari Perspektif Perlindungan Pengguna," Universiti Kebangsaan Malaysia, 2012.

[5] R. Setyowati, "Penataan Sistem Hukum Perbankan Syariah Melalui Harmonisasi Hukum Penyelesaian Sengketa Dengan Pendekatan Hukum Progresif,” Jakarta, 2015.

[6] Suteki and G. Taufani, Metodologi Penelitian Hukum (Filsafat, Teori dan Praktik), I. Depok: Rajawali Pers, 2018.

[7] C. H. Lindberg, "Certification, Status, and Salaries," J. Educ. Libr. Inf. Sci., 1990.

[8] S. Mertokusumo, Bab-Bab Tentang Penemuan Hukum. PT. Citra Aditya Bakti, 1993.

[9] S. Rahardjo, Hukum dalam Jagad Ketertiban, I. Jakarta: UKI Press, 2006.

[10] S. Rahardjo, Membedah Hukum Progresif. Jakarta: Penerbit Buku Kompas, 2008.

[11] S. Rahardjo, "Menjalankan Hukum dengan Kecerdasan Spiritual," Kompas, p. 30, 2002.

[12] S. Rahardjo, "Indonesia Membutuhkan Penegakan Hukum Progresif," Kompas, p. 39, 2012.

[13] M. I. Wahyudi, A. Z. Fanani, A. Fauzi, and M. Mahrus, "Menggantang Asa, Membangun Solusi," Direktorat Jenderal Badan Peradilan Agama Mahkamah Agung Republik Indonesia, p. 25, 2014.

[14] A. Suadi, Penyelesaian Sengketa Ekonomi Syariah,Penemuan dan Kaidah Hukum. Jakarta: Prenada Media group, 2018.

[15] A. Suadi, "Pengembangan Sumber Daya Manusia Dalam Penegakan Hukum Ekonomi Islam Di Indonesia," 2018.

[16] M. D. Hadad and K. S. Soetiono, "Strategi Perlindungan Konsumen Keuangan 2013 2027." Otoritas Jasa Keuangan, Jakarta, p. 96, 2017.

[17] M. A. Khan, "The Islamic institution of Hisbah (Ombudsman) and consumer protection," Hamdard Islam., 2012.

[18] N. Lerner, Religion, Secular Beliefs and Human Rights. 2012.

[19] A. I. Ogus, Regulation Legal Form and Economic Theory. Oregon: Hart Publishing, 2004. 